\title{
Et tabt årti? Dansk klimadækning siden COP15
}

Mikkel Fugl Eskjcer, lektor og ph.d., Institut for Kommunikation og Psykologi, Aalborg Universitet

COP15 (2009) markerede et foreløbigt højdepunkt i den danske presses doekning af klimaproblematikken. I årene efter faldt mediedoekningen med $50 \%$ og ti år efter COP15 er mediernes klimadagsorden først ved at genvinde terraen. Hvad siger disse ti års mediedakning om den danske offentligheds håndtering af klimaproblematikken? Hvor meget fylder klimaforandringer $i$ den danske dagspresse, og hvilke dagsordener er fremherskende? Norvoerende undersøgelse beskoftiger sig med de sidste 10 års klimadokning på tvaers af nyhedsmedier, herunder hvilke kilder der befolker den medierede klimadagsorden.

COP15 (2009) markerede et foreløbigt højdepunkt i den danske mediedækning af klimaproblematikken. Hverken før eller siden har medierne helliget klimaet så megen opmærksomhed. I årene efter COP15 faldt mediedækningen med 50\%, og i de følgende år forblev medieopmærksomheden på samme niveau. Det er først i takt med udviklingen frem mod COP21 og Parisaftalen, at klimadagsordenen har genvundet noget af sit tidligere momentum. Hvad siger disse ti års mediedækning om den danske offentligheds håndtering af klimaproblematikken? Hvor meget fylder klimaforandringer i den danske dagspresse, og hvilke dagsordener er fremherskende? Disse spørgsmål er omdrejningspunkt for nærværende undersøgelse af den danske klimadækning siden COP15

Hensigten med undersøgelsen er at spore mønstre og tendenser i de sidste 10 års mediedækning af klimaspørgsmålet på tværs af forskellige nyhedsmedier (presse, digitale medier) og platforme (online/offline). Medierne udgør en central kilde til befolkningens viden om klimaforandringer og tilbyder et indblik i offentlighedens interesse for klimaproblematikken. Undersøgelsen beskæftiger sig bl.a. med betydningen af såkaldte trigger-events, dvs. begivenheder som fanger mediernes interesse, samt hvilke kilder og emner der befolker den medierede klimadagsorden. I teoretisk forstand trækker undersøgelsen på medievidenskabelige teorier om miljøkommunikation, agenda-setting og nyhedskilder.

Undersøgelsens empiriske grundlag bygger på data fra Infomedias registrering af danske online og offline medier. Den metodiske tilgang udgøres af kvantitativ indholds- 
analyse. I takt med at Infomedias database indholdskategoriserer de enkelte nyhedshistorier, er det blevet muligt i højere grad at arbejde med store datasæt frem for stikprøver.

Det giver nye muligheder for at spore de overordnede udviklingslinjer i mediedækningen af klimaproblematikken, ikke mindst i relation til dominerende politiske aktører (personer og organisationer).

Teori: klima, COP15 og nyhedsmedier

Både COP15s klimapolitisk betydning og nyhedsmediernes klimadækning er fænomener, som har været genstand for talrige empiriske undersøgelser. COP15 var på mange måder en skelsættende begivenhed i international klimapolitik. Det var kulminationen på et langt forløb, som søgte at finde en afløser for Kyoto-protokollen, men som endte i en delvis fiasko. COP15 viste, at klimaforandringer er blevet et så omfattende problem, at det er vanskeligt, hvis ikke ligefrem umuligt, at nå frem til bindende aftaler. Alle efterfølgende COP-forhandlinger har måtte forholde sig til denne realitet; selv ikke den relative succes ved COP21 i Paris synes grundlæggende at have ændret på denne præmis.

I Danmark, der som bekendt var vært for COP15, blev fiaskoen oplevet som ekstra traumatisk. Værtskabet, som skulle have løftet Danmarks internationale omdømme ovenpå Muhammedkrisen, førte til det modsatte, og efterlod et indtryk af manglende forhandlingskompetencer i toppen af det politiske system og i det danske embedsværk (Meilstrup 2010); et indtryk som anden forskning har delvis modificeret med henvisning til de storpolitiske magtkampe, som også er en del af fortællingen om COP15 (Christoff 2010; Skovgaard and Blaxekjær 2013).

Studier af dansk klimadækning har dokumenteret et kraftigt omslag i mediernes klimainteresse som følge af COP15 (Jørgensen, Johansen and Kabel 2010a; Almlund 2012; Eskjær 2014). Oplevelsen af fiasko blev i medierne fremstillet som en udvikling fra top-COP til flop-COP og fra Hopenhagen til Nopenhagen. Det gav sig udslag i et kraftig fald i omfanget af mediedækning i perioden efter COP15 samt journalistisk bekymring for klima-træthed blandt læserne. En samtidig analyse fra journalisthøjskolen hæftede sig ved, at mediernes opfattelse af succes og fiasko ved COP15 hvilede på et unuanceret grundlag, som favoriserede negative historier (Jørgensen, Johansen and Kabel 2010b). I det hele taget er COP15 gået hen og blevet et referencepunkt i medievidenskabelige studier af nyhedsmediernes klimadækning både nationalt (Almlund and Danielsen 2016) og internationalt (Lidberg 2018).

Mediernes interesse for klimadagsordenen siden COP15 har været genstand for internationale og komparative studier (Schäfer, Ivanova and Schmidt 2011). De viser, at trods fluktuerende opmærksomhed er klimaet generelt forblevet en vigtig dagsorden. Nyere komparative studier (Painter and Schäfer 2018) har desuden udpeget tendenser i international klimadækning, som i et vist omfang også gør sig gældende i Danmark. Det drejer sig om en generel stabilisering af klimastoffet samt en begivenhedsdrevet medierapportering (Eskjær 2017). Klimastoffet kendetegnes desuden ved en række dominerende 
rammer [frames] såsom videnskabelig usikkerhed, katastrofe, sundhed, moral og muligheder/potentialer.

Forskningen i dansk klimadækning har været særligt koncentreret om tiden omkring, eller i kølvandet på, COP15. Det antyder, at COP15 som såkaldt trigger-event ikke blot afstedkommer større mediedækning, men også afføder større forskningsinteresse. I de senere år er der ikke publiceret større tværsnits- eller længdesnitsstudier af danske nyhedsmedier miljø- og klimadækning. I en vis forstand forekommer denne funktion at være overladt til medierne selv, som lejlighedsvis publicerer refleksioner over mediernes egen klimadækning (Mollerup 2018). Derimod har de senere år fremvist studier af klimakommunikation i mere bred forstand, herunder spørgsmål om lokal borgerinddragelse samt lokale mediers klimadækning (Horsbøl 2013; Horsbøl, Lassen and Pedersen 2015) Generelt kan det konkluderes, at den metodiske og videnskabelige mangfoldighed der hersker i internationale undersøgelser af mediernes klimadækning (Schäfer and Schlichting 2014) ikke i samme grad gør sig gældende i Danmark, hvor forskningen siden midten af 2010erne har været mere begrænset.

Det ændrer imidlertid ikke ved, at mediernes behandling af klimaproblematikken må anses for en vigtig komponent. Klimaforandringer er på mange måder en usynlig og abstrakt risiko, som ligger ud i fremtiden. Det betyder, at vi sjældent har direkte adgang til klimaforandringer. Selv de ekstremvejrsfænomener vi til tider udsættes for, og som i stigende grad tilskrives klimaforandringer, kan altid (bort)forklares som stokastiske variationer. Vores erfaringer med klimaforandring er overvejende indirekte, og der er primært gennem mediernes itale- og iscenesættelser i både nyheder og underholdning, at vi kommer i kontakt med klimaspørgsmålet. Netop fordi klimaforandringer grundlæggende udgør en medieret global risiko (Eskjær 2011), bliver det væsentligt at undersøge, hvordan klimaforandringer præsenteres i medierne, og hvem der tildeles plads til at udtale sig om klimaet. Et af de grundlæggende spørgsmål indenfor miljø- og klimakommunikation er således, hvem der taler naturens, de truede dyrarters eller klimaets sag (se fx. Boykoff 2011).

\section{Klimadagsorden}

Agenda-setting er en af de primære teorier om, hvordan medierne øver indflydelse på politisk kommunikation. Der er tale om et teorikompleks, som er udviklet gennem 50 års medieforskning. I sin oprindelig form handler teorien om, hvorvidt befolkningens vurdering af politiske emner afhænger af den opmærksomhed, som medierne tillægger dem (McCombs and Shaw 1972). Teorien antager således, at medierne har indflydelse på hvad befolkningen tænker på og opfatter som væsentligt. Oprindeligt beskæftigede agendasetting teori sig alene med korrelationen mellem budskabsfrekvens og politiske meningsmålinger. Senere har teorien udviklet sig i retning af agenda-setting af anden orden (McCombs 2004), som ikke blot angår hvad medierne sætter på dagsordenen, men også spørgsmålet om hvordan denne dagsorden konstrueres (indrammes). 
En anden teoriudvikling fremhæver, at mediernes dagsorden må sættes i relation til både politikernes og publikums dagsorden, samt i hvilket omfang den pågældende dagsorden afspejler et virkeligt problem [real world agenda] (Dearing and Rogers 1996). Udfordringen for en sådan udvidet dagsordenteori er imidlertid, at den involverer et stort antal variationsmuligheder. Det medfører, at en empirisk bestemmelse af den kausal retning for denne agenda-setting bliver vanskelig at måle (McQuail 2010, 513).

Inden for klimakommunikation er agenda-setting et populært analytisk redskab. Eftersom klimaforandringer er en abstrakt og delvis usynlig risiko, må man at antage, at bekymringen for klimaforandringer hænger sammen med, hvor meget vi eksponeres for viden og debat herom, og at medierne udgør en central arena for denne information.

\section{Klimakilder}

Når man beskæftiger sig med mediernes dagsorden, er det nærliggende at undersøge, hvilke kilder som kommer til orde inden for denne dagsorden. Sammen med dagsordensteori hører kildeteori således til medieanalysens klassiske værktøjer. Der findes grundlæggende to slags teori om nyhedskilder. Dem der ser på relationerne mellem journalist og kilde, hvilket angår spørgsmål om tillid, magt og interpersonelle netværk. Og de mere strukturelle kildemodeller som undersøger autoritets- og kildehierarkier, og hvordan disse strukturer prædisponerer journalister og favoriserer institutionelle kilder. I forbindelse med nærværende undersøgelses er det sidstnævnte model, som er mest relevant.

En af de klassiske modeller antager, at journalister opdeler kilder i tre kategorier eller regioner, som hver er underlagt forskellige normer. Omdrejningspunktet for modellen er den midterste region, som udgør en sfære for "legitim kontrovers" (Hallin 1986, 116), hvilket kan være lovforslag, ideologiske modsætninger mellem parlamentariske partier, udspil fra interessegruppe mm. Det er her, vi finder den klassiske journalistiks balancenorm og objektivitetsideal, hvor flere sider af samme sag bliver belyst gennem udsagn fra uafhængige kilder.

De to øvrige sfære fungerer med et udtryk fra Talcott Parsons som "grænse-bevarende mekanisme" (Hallin 1986, 117). Dvs. at de tjener til at bevare og fastholde grænserne for legitim kontrovers og dermed den klassiske journalistik. På den ene side afgrænser legitim kontrovers sig fra en konsensussfære, hvor journalistikkens balancenorm i en vis forstand opfattes som overflødig, fordi vi har at gøre med "sociale objekter", der under normale omstændigheder opfattes som ukontroversielle og/eller autoritative (det politiske system formellem repræsentanter, kongehuset, gejstlige overhoveder etc.). I den sammenhæng bliver journalistikkens opgave at fejre social og politisk konsensus snarere end at agere samfundsmæssig vagthund, fx i forbindelse med videnskabelige paradigmer eller sociale ceremonier (nytårstaler, kongelige begivenheder, bisættelser, historiske hændelser).

På den anden side afgrænses den traditionelle journalistisk af en såkaldt afvigelsessfære. Sidstnævnte består af de: "politiske aktører og synspunkter som journalister og 
samfundets politiske mainstream afviser som uværdige" (Hallin 1986, 117). Her opretholdes sfæren for legitim kontrovers ved at udgrænse synspunkter og kilder som eliten og den politiske mainstream ikke betragter som stuerene i politisk forstand.

Grænserne mellem de tre sfærer er flydende. Dels ændrer de sig over tid, dels afhænger de af det pågældende nyhedsområde. Fx er grænserne for afvigelsessfæren anderledes, når det handler om flygtninge og indvandrere, end når stofområder er økonomisk politik. I førstnævnte tilfælde er rammerne for kilder, udsagn og billedsprog udvidet betragteligt over de sidste årtier, hvorimod det økonomiske nyhedsområde stadig domineres af relativt specialiserede kilder og antagelser.

Kampen om at sætte en dagsorden i medierne udspiller sig i sfæren for legitim kontrovers, eftersom kilderne i konsensussfæren ikke modsiges, og kilderne i afvigelsessfæren grundlæggende er udgrænsede. Dette forhold er søgt indfanget med begrebet om "primary definers" (Hall 1978, 57). Antagelsen er, at nyhedsmediernes normer for objektivitet, balance, og upartiskhed favoriserer en særlig type af kilder, nemlig autoritative og institutionelle kilder såsom myndigheder, repræsentanter for det politiske system eller interessegrupper. Udsagn fra disse kilder opfattes traditionelt som objektive og autoritative. Dels fordi de befinder sig øverst $i$ et autoritetshierarki og dermed antages at have mere præcis og specialiseret viden om et givent emne. Dels fordi disse kilder anses som "repræsentative", fx ved at være folkevalgte eller varetage særlige interessegrupper (Hall 1978, 58). Resultat er, at disse kilder bliver systematisk over-repræsenteret i medierne.

Rollen som "primary definer" er yderst magtfuldt, fordi det tillader disse kilder at konstruere et sagsforhold og dermed sætter en dagsorden for efterfølgende nyhedsdækning og debat. Ganske vist forbliver primary definers sjældent uimodsagte; det sikrer journalistikkens balancenorm og brug af uafhængige kilder. Men alle efterfølgende kilder tvinges ind i de rammer og præmisser, som de institutionelle primary definers allerede har opsat. I den forstand præ-defineres et givent socialt problem af primary definers, hvilket efterfølgende gør det vanskeligt at tilbyde alternative forståelser og løsningsmodeller (Hall 1978, 58).

Teorien om primary definers er blevet kritiseret for at overse, at der til tider hersker både uenighed og konkurrence mellem primary definers. Et eksempel herpå er den konkurrence mellem Statsministeriet og Klima- og Energiministeriet som ifg. Meilstrup herskede i optakten til COP15 (Meilstrup 2010, 128). Andre kritikpunkter anfører, at officielle kilder ofte udtaler sig anonymt, off-the-record eller formidler privilegeret information uden navns nævnelse, hvilket undergraver magten hos primary definers (Allan 2010,85 ). Endelig er modellen ahistorisk og overser, at nye medieteknologier (fx wikileaks) eller institutionelle tiltag (fx whistleblower-ordninger) ændrer vilkårene for primary definers. Ikke desto mindre står begrebet centralt i medievidenskabelige fremstillinger (Allan 2010; Lester 2010), da det formår at begrebsliggøre det sammenfald, som hersker mellem mediernes dagsorden og samfundets herskende ideer. Samtidig undgår begrebet at reducere dette forhold til en lineær politisk økonomi (ejerskabsrelationer), men lokaliserer det derimod i mediesystemets operationsformer og kildepraksis. 
Data og metode

Med henblik på at afdække de store linjer i dansk klimadækning siden COP15 er undersøgelsen struktureret omkring følgende to undersøgelsesspørgsmål:

U1: Hvordan har dansk klimadækning udviklet sig siden COP15?

U2: Hvem befolker danske klimanyheder?

Undersøgelsen bygger på principperne for kvantitativ indholdsanalyse (Eskjær and Helles 2015) og er designet til at udnytte og udforske de muligheder, som digitale databaser tilbyder analysen af medieindhold. Den danske database Infomedia har siden begyndelsen af 1990erne registreret indhold i danske nyhedsmedier og omfatter i dag alle danske medier. Desuden er Infomedia med årene blevet udbygget med nye kategorier og søgefunktioner. Det er således muligt at foretage analyser af medieindhold vha. søgeord og bryde disse søgninger ned på fx tidsintervaller, medieplatforme, personer og organisationer. Den anvendte søgestreng er "klimaforandring* OR global* opvarmning", hvilket betyder, at alle nyhedshistorier med variationer af ordene klimaforandring eller global opvarmning er blevet medtaget.

Ved at benytte Infomedias egne kategoriseringer, er det muligt at foretage undersøgelser over en længere periode baseret på totaltællinger. Det giver mulighed for at afdække mønstre i dansk klimadækning, som ville være vanskeligt at indfange vha. stikprøver og manuel kodning. Undersøgelsen trækker således på et omfattende artikelmateriale, som dækker perioden 2000-2018 (n=223092) med særlig vægt på perioden 2009$2018(\mathrm{n}=179152)$

\section{Mediernes klimadagsorden: udvikling og vilkår}

Skal man vurdere udviklingen i den danske mediedækning af klimaforandring siden COP15, kan det være hensigtsmæssigt at anskue perioden i et større perspektiv. Fig. 1 viser udviklingen i dansk klimadækning fra 2000 til 2019 og indbefatter alle danske nyhedshistorier om klimaforandring eller global opvarmning. 




Figur 1: Danske klimanyheder 2000-2018

Figuren viser, at klimadækning først bliver en mediedagsorden fra midten af 00erne. På samme tid begynder webkilder at spille en vigtig rolle. Før 2004 udgør webkilder en begrænset del af mediedækningen, men fra 2005-2008 udgør de omkring en tredjedel, og fra 2009 cirka halvdelen, af danske klimanyheder.

Figuren indikerer desuden et sammenfald mellem dansk klimadækning og såkaldte "trigger-events", dvs. klimabegivenheder, der afføder stor mediebevågenhed. 2007 er året for IPCCs fjerde Assessment Report, som slog fast at den globale opvarmning er "unequivocal" og at det "very likely" skyldes menneskeskabte drivhusgasudledninger (IPCC 2007, 30, 39). 2009 var året for COP15, som sprængte alle rammer for klimadækning, særligt i Danmark, men også i mange andre lande. Mediernes fornyede interesse for klimaforandring begynder i 2014, som er året for IPCCs femte Assessment Report, og som fastslog at "Human influence on the climate system is clear" (IPCC 2014, 2). Medieinteressen skærpes yderligere i 2015, hvor COP21 blev afholdt i Paris.

Endelig markerer 2018 et nyt højdepunkt i klimadagsordenen, hvor to større internationale klimabegivenheder finder sted. For det første udkom IPCCs særlig rapport om følgerne af global opvarmning på $1,5^{\circ} \mathrm{C}$ over førindustrielt niveau. Rapportens opdrag var at undersøge effekten af den globale opvarmning "in the context of strengthening the global response to the threat of climate change" (IPCC 2018,6). Som sådan var rapporten en opfølgning på Paris-deklarationens opfordring til at "limit the temperature increase to $1.5{ }^{\circ} \mathrm{C}$ " (UNFCCC 2015, 2). Den anden vigtige begivenhed var COP23 i Polen, som 10 år efter fiaskoen i København formåede at komme til enighed om et fælles regelsæt for implementeringen af Paris-deklarationens målsætninger. 


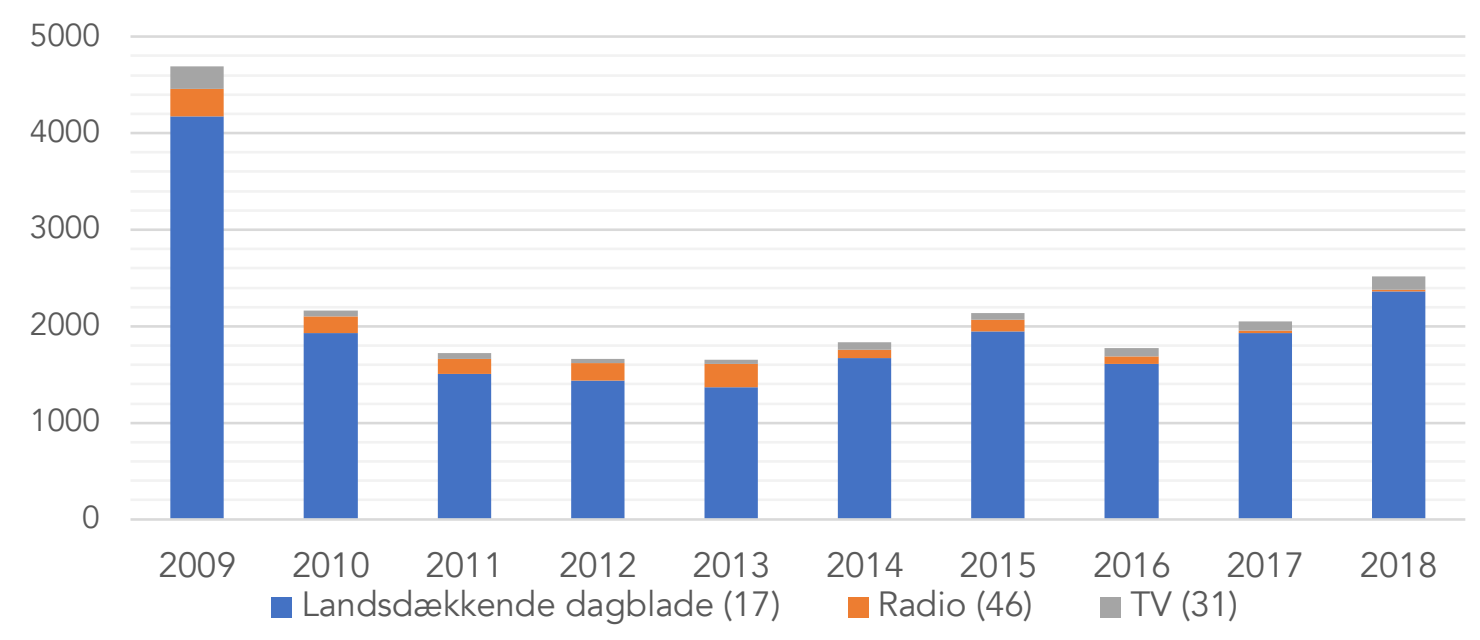

Figur 2: Den danske presses klimadækning 2009-2018

Zoomer man ind på de seneste år af dansk klimadækning og sammenligner med perioden 2007-2008 (fig. 1), så aftegner der sig en interessant udvikling. Hvor den samlede mediedækning i 2014 tangerer optakten til COP15 (2007), så gør det samme sig ikke gældende, hvis man ser isoleret på den traditionelle presse (aviser, radio og tv). Her ligger tallet $\mathrm{i}$ 2018 ( $\mathrm{n}=2516)$ stadig lavere end i 2007 ( $\mathrm{n}=3619)$ og 2008 ( $\mathrm{n}=2817)$.

Det siger formodentlig noget om effekten af COP15 på dansk klimadækning. Skønt den overordnede udvikling i Danmark følger et internationalt mønster med et kraftigt fald efter COP15 og en stigende interesse frem mod COP21 i Paris (se Boykoff 2019), så har udviklingen i Danmark været en kende mere dramatisk. Dels var faldet i mediedækningen mere voldsomt, dels har det taget klimadagsordenen i Danmark længere tid at komme tilbage på højt niveau (Infomedia 2014). Det hænger muligvis sammen med Danmarks rolle som vært for COP15. Det er en velkendt effekt, at medierne filtrerer og "domesticerer" internationale begivenheder ud fra nationale perspektiver (Lee et al. 2005). For Danmark handlede COP15 ikke blot om at finde en afløse for Kyotoprotokollen, men også om international anseelse. Af samme årsag blev fiaskoen og efterdønningerne af COP15 særligt traumatiske, fordi det afslørede svagheder i det politiske systems evne til at håndtere internationale forhandlinger på højt niveau, og udstillede interministeriel konflikt og konkurrence.

Ikke desto mindre er det værd at fastholde, at trods et massivt fald i mediedækningen på over 50\% i årene efter COP15 så er klimadækningen forblevet højt. Ser man bort fra år 2009 som en outlier, så er der desuden tale om en relativt stabil dagsorden. Det illustreres i fig. 3, som sammenligner klimadagsordenen med andre traditionelle mediedagsordener indenfor økonomi (finanslov, skattelettelser), miljø (forurening) og samfund (kriminalitet). Klimaforandring fylder ikke lige så meget som klassiske temaer som kriminalitet eller landets finanslov, men er på niveau med et populært politisk tema om skattelettelser. Desuden er klima tydeligvis blevet det dominerende tema på mediernes miljødagsorden, hvor det overgår den traditionelle interesse for forurening. 




Figur 3: Temaudvikling i landsdækkende dagblade 2009-2019

En del af forklaringen på klimaets placering i nyhedsbilledet er formodentlig, at mediernes klimadagsorden delvis flugter med befolkningens og politikernes dagsorden. Eurobarometer-undersøgelser viser, at den danske befolkning i stigende grad er bekymret for risikoen for klimaforandringer (EC 2018, 14). I de kvartalsmålinger, som Eurobarometer udfører i EU's medlemslande, er et tilbagevendende spørgsmål, hvad respondenten på det givne tidspunkt opfatter som de (to) vigtigste "issues". En af de tyve svarmuligheder er "miljøet, klima og energi-spørgsmål”. I perioden 2009-2012 svingede andelen af danskere som angav "miljø, klima og energi" mellem $11 \%$ og 8\%, men steg i perioden 2011 2014 fra 8\% til 13\%. I de efterfølgende år fra 2014-2016 sker der et fald fra 13\% til 9\%, som dog afløses af en næsten jævn stigning mellem 2016 og 2018 fra 9\% til 18\%. Korrelationen mellem mediernes og befolkningen klimadagsorden er således størst indenfor de sidste 3-4 år, men dog med relativt ens udsving henover perioden, hvis man ser bort fra 2009.

På samme tid er det sket en "mainstreaming" af klimaforandringer indenfor den politisk dagsorden, dvs. at klimaproblematikken i stigende grad integreres i forskellige politikområder. Endelig har klimavidenskaben gang på gang fremlagt evidens for klimaforandringer som et virkeligt problem [real world agenda], fx ved at påvise at de sidste fire år har været de varmest registrerede år nogensinde (WMO 2019), ligesom otte ud af de ti varmeste år er indtruffet siden 2009 (Climate Central 2019).

Der er imidlertid også andre forhold, der kan bidrage til at forklare klimadagsordenens omfang. En af de store udfordringer ved klimaproblematikken er, at den ikke kan 
isoleres til en enkelt sektor. Klimaforandring angår stort set hele indretningen af den moderne tilværelse fra transport, bolig, fødevareproduktion, forbrug, fritid og livsstil, hvilket er blevet beskrevet som vores "high carbon life" (Urry 2011, 48). Resultatet er, at klimaforandringer flettes ind i stort set alle nyhedsområder.

Der er blevet gjort forskellige forsøg på at begrebsliggøre dette forhold. Indenfor den litterære økokritik har Timothy Morton introduceret begrebet hyper-objekt, der betegner: "things that are massively distributed in time and space relative to humans" (Morton 2013, 1). Klimaforandring er netop et eksempel på et fænomen, som er "so massively distributed we can't directly grasp them empirically" (Morton 2016, 11). Tidligere har kulturgeografen Mike Hulme omtalt klimaforandringer som et "mega-problem" (Hulme 2009, 333) med henvisning til begrebet om "wiked problems". Sidstnævnte refererer til problemer som er unikke, som er symptom på noget andet (fx overforbrug) og som grundlæggende er uløselige pga. indbyggede interdependencer og feedback mekanismer (Rittel and Webber 1973). En senere teoriudvikling har med henvisning til klimaforandringer tilføjet endnu et adjektiv og taler om super-wicked problems (Levin et al. 2012). Her forstærkes problemet ved at tiden løber ud, at der ikke findes en central autoritet som kan koordinere (klima)indsatsen, og at reaktionen på problemet er præget af korttidsplanlægning.

Der knytter sig en række kommunikative udfordringer til sådanne mega-problemer, hyper-objekter eller super-wicked problemer. For det første overskrider de nyhedsmediernes traditionelle stofområder og blander videnskab, politik, økonomi, teknologi og kultur. For det andet fordrer de en specialiseret faglig og teknisk viden, som ofte rækker ud over nyhedsinstitutioners kompetencer, der i stigende grad er i skarp konkurrence med onlinemedier præget af hurtige opdateringer. Endelig passer disse massive, uløselige og langstrakte problemer dårligt til nyhedsmediernes generelle præference for veldefinerede begivenheder, korte og utvetydige historie samt fokus på personligheder og underholdning. Dog kompenserer klimadagsorden herfor på enkelte punkter. De globale risici ved klimaforandringer kan fx italesættes som katastrofiske dommedagsscenarier, hvilket appellerer til præferencen for det sensationelle, ligesom modsætninger mellem videnskab/industri, regulering/markedskræfter, mitigation/adaptation, udviklingsland/industrilande osv. passer til mediernes konflikt-indramning.

Samlet set har det medført en klimadækning, der ikke hører hjemme indenfor et enkelt stofområde, men som optræder i mange forskellige sammenhænge. Et historisk blik på mediernes klimadagsorden vidner herom. Oprindeligt var klimaproblematikken tilknyttet en overvejende videnskabelig diskurs, som i løbet af 1980erne blev overtaget af en overvejende politisk diskurs (Danielsen 2015, 78). Global opvarmning blev ligeledes præsenteret i forlængelse af globale miljøproblemer og hørte til under avisernes miljødækning, før den i visse nyhedsmedier fik egen klimasektion. Under den massive mediedækning i årene omkring COP15 blev klimaet relateret til stort set alle stofområder (Eskjær 2014) for så at glide i baggrunden i årene efter. I samme periode forsvandt klima 
som selvstændig sektion i trykte og online aviser. I de senere år er specifikke klimasektioner igen begyndt at se dagens lys i forbindelse med den fornyede medieinteresse for klimaforandringer.

Det peger på, at hvor selve klimadagsordenens omfang har udviklet sig relativt stabilt $i$ det samlede nyhedsbillede, så har den redaktionelle prioritering i de enkelte mediehuse til tider været mere ujævn. Et eksempel herpå er Politiken som i nov. 2018 erklærede, at avisen ville være "Danmarks førende klimaavis" (Jensen 2018). Denne redaktionelle beslutning har betydet, at Politiken har (gen)indført en jævnlig klimasektion, hvilket har øget omfanget af avisens klimadagsorden betragteligt. I de fem måneder før Politiken lancerede sin ambition om at være "Danmarks klimaavis nr. 1", trykte avisen 247 klimaartikler svarende til ca. 1,65 artikel pr. dag. I de fem måneder efter dette tiltag er omfanget steget med næsten $40 \%$ til 343 artikler svarende til et dagligt gennemsnit på ca. 2,3 klima relateret artikel. Hvis denne udvikling afspejler en mere generel tendens, tyder det på, at vi er på vej mod et nyt toppunkt i mediernes klimadækning.

Hvem taler klimaets sag? Kilder i dansk klimadækning

En anden måde at undersøge, hvordan nyhedsmedierne dækker klimaproblematikken, er ved at se på de kilder, som dominerer klimadagsordenen. Der findes grundlæggende to typer af kilder; individer eller organisationer. Som det vil fremgå, hænger de to tæt sammen, da mediernes dominerende kilder næsten uden undtagelse opnår deres autoritet ved at være "repræsentative" for en samfundsinstitution. Forskellen er, at fokus på personer giver et mere broget billede, hvorimod fordelingen af institutionelle kilder er mere stabilt og samtidig indfanger andre typer af aktører.

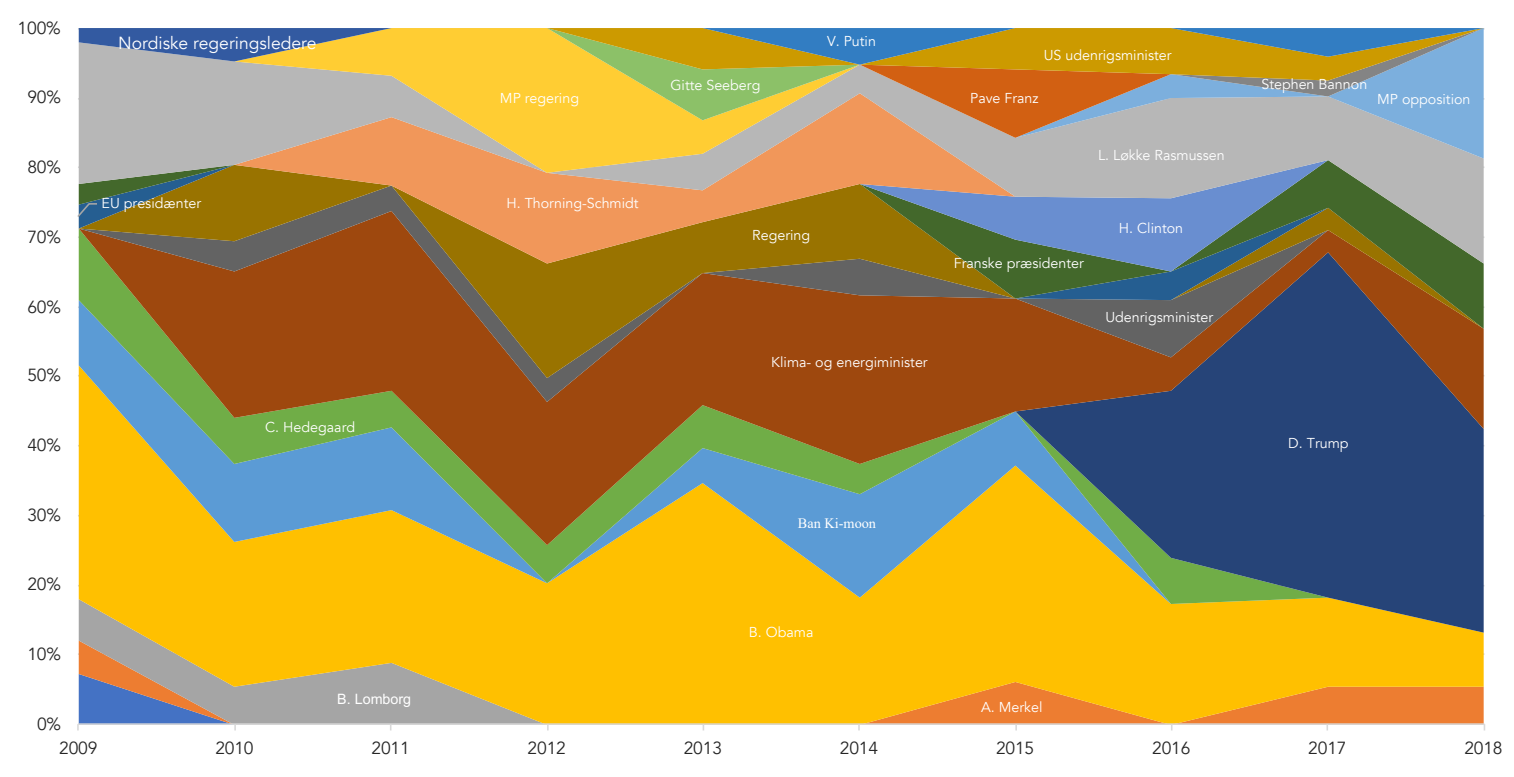

Figur 4: Top 10 kilder pr. år i dansk klimadækning 2009-2018 
Fig. 4 viser udviklingen det sidste tiår over de ti dominerende kilder i den samlede danske mediedækning, dvs. på alle platforme $(\mathrm{n}=59145)$. I tilfælde af funktionssammenfald, fx forskellige udenrigsministre, er personer blevet slået sammen i en fælles kategori for at skabe et mere klart overblik. Desuden angiver figuren den indbyrdes fordeling (i procent) blandt disse kilder. Figuren viser, at klimadækningen befolkes af elitepersoner, og at der er tale om en meget international dagsorden. Med meget få undtagelser kommer top ti kilder fra toppen af det nationale eller internationale politiske system.

Overvægten af politiske kilder viser, at mediernes dominerende personkilder stort set udelukkende stammer fra sfæren af legitim kontrovers. Faktisk er der blandt top ti kilder kun tre personer, som ikke er direkte tilknyttet det formelle politiske system. Det drejer sig i første omgang om Gitte Seeberg, der som generalsekretær for Verdensnaturfonden repræsenterer en moderat miljøorganisation. Desuden er Seeberg tidligere medlem af folketinget (for Konservative og Liberal Alliance) og således solidt placeret i sfæren for legitim kontrovers.

Pave Franz, som var blandt top ti kilderne i 2015, er derimod en anden type kilde, der nærmer sig konsensussfæren. Som overhoved for den katolske kirke besidder paven en autoritet, som sjældent bestrides, specielt ikke når det angår mere verdslige forhold som miljø og klima. Eksempelvis opfordrede sognepræsten ved Marmorkirken til at "Lyt[te] til Vatikanet" i forbindelse med pavens rundskrivelse om klimaproblematikken (Wold 2015). Det betyder ikke, at pressens kritiske rolle forstummer. Bjørn Lomborg brugte rundskrivelsen til at hævde, at "Paven har forkerte løsning på det rette problem" (Lomborg 2015). Men generelt var kritikken af pavens position afdæmpet, og markerer dermed en grænse for, hvordan miljøpolitiske spørgsmål normalt behandles indenfor sfæren af legitim kontrovers, hvor der som regel optræder en bred vifte af uafhængige og/eller kritiske kilder.

Netop Bjørn Lomborg er en farverig kilde, der skiller sig ud fra det øvrige kildemateriale. Fra 2009-2011 var Lomborg blandt top ti kilder i klimaspørgsmålet, og han er forblevet en vigtig stemme, skønt henvisningerne er faldt til 22 nyhedshistorier i 2017. Lomborg kan betragtes som et eksempel på dansk klimaskepticisme; en position som har fyldt meget $i$ angelsaksiske lande, men som med undtagelse af Lomborg har været relativt marginaliseret i dansk klimadækning. Lomborgs klimaskepticisme er da også pakket ind i cost-benefit-analyser, der ikke direkte benægter eksistensen af klimaforandringer, men snarere problematiserer de løsningsmodeller der udgår fra FN-systemet og det internationale samfund (Lomborg 1998, 2007). I forbindelse med COP15 hævdede Lomborg således, at global opvarmning kan være en fordel (Lomborg 2009b) og at klimaproblematikken kan løses vha. geo-enginering (Lomborg 2009a). Desuden har en gennemgående kritik fra Lomborgs side været, at medierne fejlrapporterer og er for kritiske, når det angår klimaforandringer (Lomborg 2001, 39).

Man kan udlægge Lomborgs succes forskelligt, men det peger i mange tilfælde på forhold, der går ud over Lomborg som person. På den ene side repræsenterer Lomborg en pluralisme, som nyhedsmedierne er forpligtet på ved at tilbyde en platform for modstridende holdninger. Man skal i den forbindelse huske, at Lomborg på mange måde er et 
mediefænomen, som blev "opfundet" af Politiken. I 1998 bestilte avisen fire kronikker af Lomborg, som senere dannede baggrund for Lomborgs bog Verdens Sande Tilstand (1998).

På den anden side har Lomborg gennem årene fremført en stribe forskellige budskaber om klimaforandringer. Fx at der findes bedre forklaringer på klimaforandringer, end at de er menneskeskabte, at klimaforandringer kan være en fordel, at det ikke kan betale sig at løse klimaforandringer på nuværende tidspunkt eller at vi bør afvente tekniske løsninger. Sådanne delvis inkohærente budskaber resulterer i at mudre billedet af klimaforandringernes "sande tilstand". Og her minder Lomborg om andre aktører, der helt bevidst arbejder på at så tvivl om klimavidenskaben. Det er en strategi, som trækker på succesfulde erfaringer fra tobaksindustrien, der i mange år lykkedes med at betvivle sammenhængen mellem rygning og lungekræft. Strategien er senere blev gentaget i forbindelse med syreregn, ozonlagshuller og senest klimaforandringer (Oreskes and Conway 2010).

Det peger på en mere grundlæggende journalistisk problemstilling om forskellige former for viden og usikkerhed. Dette forhold er i længere tid blevet beskrevet som balanceproblematikken (Boykoff and Boykoff 2004, 2007). Nyheder søger som regel at gengive minimum to sider af samme sag med henblik på at opnå en "objektiv" og upartisk sagsfremstilling. Det giver naturligvis mening, når det handler om politisk viden, der netop er kendetegnet ved modstridende synspunkter og positioner, fx om en kulstofskat er en god løsningsmodel på global opvarmning. Men samme balancenorm giver nødvendigvis ikke mening, når det handler om naturvidenskab. Ofte hersker der hverken usikkerhed eller legitime kontrovers om videnskabelige fakta. Som en amerikansk redaktør engang har bemærket, så ringer journalister jo ikke til flat earth society, hver gang en satellit sendes i kredsløb om jorden.

Spørgsmålet er i den sammenhæng, hvordan medierne opfatter grænsen for videnskabelige konsensus og dermed legitim kontrovers. Set i lyset af den faldende mediedækning af klimakontrære positioner synes danske medier i stigende grad at følge den videnskabelige konsensus på området. Undersøgelser viser en konsensusrate på 97\% i forskningsmiljøet hvad angår vurderingen af klimaforandringer som menneskeskabte (Cook et al. 2016). Det peger på, at danske nyhedsmedier med årene har fået en mere afklaret forståelse af, hvad usikkerhed på klimaområdet indebærer, hvilket i samme ombæring indikerer, at Lomborgs position har bevæget sig fra centrum af sfæren for legitim kontrovers i retning af afvigelsessfæren.

\section{Organisationer og institutionelle kilder}

Eftersom fokus på dominerende personkilder favoriserer elitekilder, udgør referencer til institutioner og organisationer et andet mål for, hvem der sætter mediedagsordenen. Fig. 5 tilbyder et sådant alternativt overblik. Den viser de ti mest omtalte organisationer $(n=144565)$ i den samlede mediedækning fra 2009-2018. 


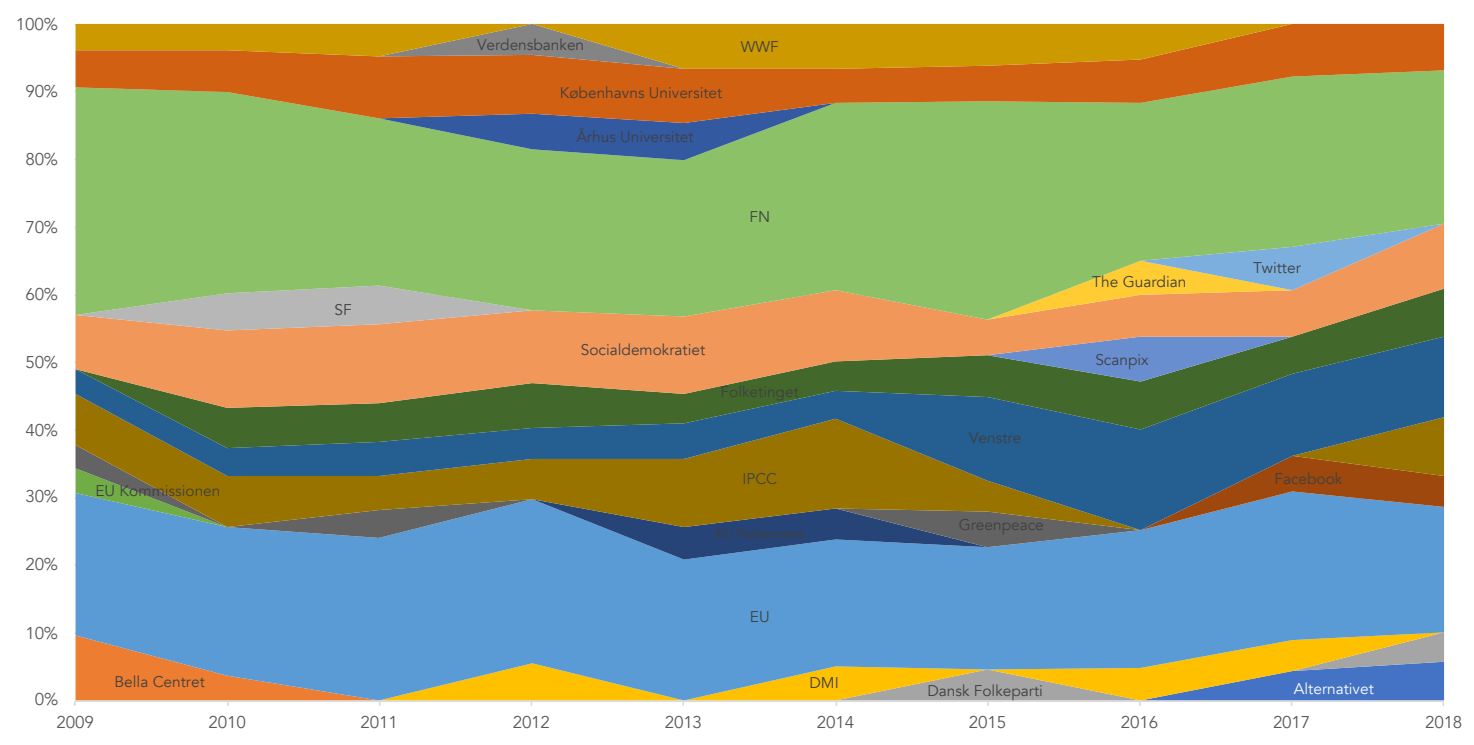

Figur 5: Top 10 organisationer pr. år i dansk klimadækning 2009-2018

Sammenlignet med fig. 4 præsenteres vi for et mere stabilt billede, som afspejler at personer kommer og går, hvorimod organisationer består. På det overordnede plan genfinder man dog de samme mønstre. Det er således eliteinstitutioner fra det politiske system der dominerer, herunder Folketinget, EU-parlament, EU-kommissionen, regeringspartier (Venstre og Socialdemokratiet), regeringspartnere (SF) samt støttepartier (DF). En interessant undtagelse er Alternativet, som i to år sniger sig ind på top-10, hvilket viser, at partiet har haft held med at præsentere sin klimadagsorden. Derudover er IGO'er stærkt repræsenteret i den danske klimadækning. Det drejer sig først og fremmest om FN og IPCC, som er verdenssamfundets primære politiske og videnskabelige aktører på klimaområdet. Henvisninger til IPPC topper i 2009, 2014 og 2018, hvilket afspejler IPCCs rolle under COP-processen, men også som afsender af de klimarapporter, der danner grundlag for verdenssamfundets klimaforhandlinger.

Figuren indfanger imidlertid også aktører, som ikke fremtræder i en personorienteret kilderegistrering. For det første viser fig. 5, at mange kilder udtaler sig som repræsentanter for videnskabelige ekspertorganisationer (Københavns Universitet, Århus Universitet og DMI). Det illustrerer, at klimaproblematikken repræsenterer en videnstung og specialiseret dagsorden. For det andet viser figuren, at klimadagsordenen ikke alene domineres af kilder fra det formelle politiske system, men at civilsamfundet også bliver hørt. Siden COP15 har Verdensnaturfonden været blandt top ti kilder i syv år og Greenpeace i tre år, hvilket vidner om en mere varieret sfære af legitim kontrovers.

Endelig viser figuren, at nye medieplatforme er begyndt at påvirke klimadagsordenen i analyseperiodens sidste år. Det illustrerer et velkendt fænomen, hvor medierne i et vist omfang tjener en rekursiv funktion og bliver hinandens kilder. Når den britisk avis The Guardian optræder i figuren, hænger det sammen med, at avisen allerede for nogle år siden lancerede sig som en slags internationalt talerør på klimaområdet (Rusbridger 2015). Tilstedeværelsen af Facebook og Twitter vidner derimod om forandringer i det 
internationale medielandskab, hvor sociale medier i stigende omfang påvirker nyhedsflowet. Facebook og Twitter giver plads til nye kilder og til andre måder at agere på i nyhedsbilledet. Undersøgelser peger på, at sociale medier i stigende grad er blevet en vigtig journalistisk kilde (Broersma and Graham 2013). Dels til at holde sig ajour og opdateret, men også fordi mikro-blogs som Twitter gør det muligt at gengive mere personlige vinkler på et abstrakt emne.

\section{Konklusion}

Umiddelbart kunne det se ud som om, at tiden efter COP15 har været et tilbageskridt, måske ligefrem et tabt årti, hvor klimadækningen aldrig har genvundet pusten. Som anført udgør perioden 2007-2009 et højdepunkt i dansk klimadækning, som pressen endnu ikke har indhentet. Samtidig har rapporter fra IPCC og gennemsnitlige globale temperaturmålinger gjort det klart, at klimakrisen kun er blevet værre siden 2009. I den forstand kan man tale om en afkobling af mediernes klimadagsorden og klimaproblematikkens real world indikatorer.

I samme tidsrum har mediernes og befolkningens klimadagsorden udvist varierende tendenser. I starten af perioden faldt klimadækningen på dramatisk vis i modsætning til den offentlige klimadagsorden, som kun udviste små udsving. Omvendt har mediernes klimadagsorden i perioden 2016-2018 slet ikke har fulgt med stigningen i befolkningens bekymring for miljø og klima, som er fordoblet fra 9 til 18\%. I de mellemliggende år har udsvingene i mediernes og befolkningens klimadagsorden til gengæld været relativt ens.

I ren kvantitativ forstand kan tiåret siden COP15 altså betragtes som en afmatning, hvor det momentum som var blevet opbygget fra 2007-2009 blev forpasset, og hvor medierne ikke formåede at fastholde en klimadagsorden og klimabekymring, som står mål med de udfordringer, vi står overfor. Endvidere synes medierne relativt sent i perioden at følge trop med befolkningens fornyede bekymring og mobilisering for klimaproblematikken (fx skolestrejker og klimamarcher).

Når man alligevel skal være varsom med at dømme perioden 2009-2019 for et tabt årti, hænger det sammen med, at der er andre aspekter af danske klimadækning, som nuancerer billedet. Ser vi bort fra dækningen i 2009, som var exceptionel høj, er der måske mere tale om en stagnation, hvilket peger på, at klimadagsordenen har bidt sig fast og dækkes bredt i den danske offentlighed. Hvor den personorienterede kildeoptælling afslørede en omfattende overrepræsentation af elitekilder fra det politiske system, viste figuren over institutionelle kilder, at sfæren for legitim kontrovers er mere omfattende, og at civilsamfund, IGOer og ekspertorganisationer tilhører klimadagsordenens vigtigste kilder.

Undersøgelsens tiårige perspektiv påviser desuden, at klimadagsordenen langt fra er statisk, selv når man som i denne undersøgelse begrænser sig til de store linjer. Ser vi 
på kildesammensætning fremfor artikelfrekvens, viser undersøgelsen, at dansk klimaskepticisme i stigende grad udgør en marginaliseret position i klimadebatten, hvorimod FN-systemet og de videnskabelige institutioner er forblevet vigtige aktører. Klimaproblematikkens globale karakter medfører desuden, at den lægger sig tæt op ad udviklingen i international politik, hvilket de mange referencer til Trump vidner om. Trump administrationens regressive klimapolitik har forstyrret det internationale klimasamarbejde, hvilket tydeligvis har genereret mange nyhedshistorier. Endelig er klimadækningen blevet overhalet indenom af nye sociale medier, som nu er med til at sætte klimadagsordenen. Mediedækningen folder sig dermed om sig selv og påvirker ikke blot befolkningens og politikkernes klimainformation, men også sin egen medierede klimadagsorden. Set $\mathrm{i}$ det lys er der ekstra god grund til fortsat at holde øje med, hvordan medierne italesætter det, som er blevet kaldt "the biggest story of our time" (The Guardian 2015).

\section{Litteratur}

Allan, S. (2010). News culture. $3^{\text {rd }}$ ed. Maidenhead, New York: McGraw-Hill/Open University Press.

Almlund, P. (2012). Negotiating and Communicating Climate. In: Almlund, P., Jespersen, P. H., and Riis, S., eds, Rethinking climate change research: clean technology, culture and communication. Farnham: Ashgate, pp. 295-313.

Almlund, P. and Danielsen, O. (2016). Det Hjemløse Klima. In: Blach-Ørsten, M. and Willig, I., eds, Den falles dagsorden og alle de andre. Copenhagen: Samfundslitteratur.

Boykoff, M. (2019). World Newspaper Coverage of Climate Change or Global Warming, 2004-2019. Center for Science and Technology Policy Research, Cooperative Institute for Research in Environmental Sciences, University of Colorado, Media and Climate Change Observatory Data Sets. Available at: https://sciencepolicy.colorado.edu/icecaps/research/media_coverage/world/index.html [Accessed: 8 May 2019].

Boykoff, M. and Boykoff, J. M. (2004). Balance as bias: global warming and the US prestige press. Global Environmental Change, vol. 14(2), pp. 125-136.

Boykoff, M. and Boykoff, J. M. (2007). Climate change and journalistic norms: A casestudy of US mass-media coverage. Geoforum, vol. 38(6), pp. 1190-1204.

Boykoff, M. T. (2011). Who Speaks for the Climate? Making Sense of Media Reporting on Climate Change. Cambridge: Cambridge UP.

Broersma, M. and Graham, T. (2013). Twitter as a news source: How Dutch and British newspapers used tweets in their news coverage, 2007-2011. Journalism Practice, vol. 7(4), pp. 446-464. https://doi.org/10.1080/17512786.2013.802481 
Christoff, P. (2010). Cold climate in Copenhagen: China and the United States at COP15. Environmental Politics, vol. 19(4), pp. 637-656. https://doi.org/10.1080/09644016.2010.489718

Climate Central (2019). The 10 Hottest Global Years on Record. Climate Central. Available at: https://www.climatecentral.org/gallery/graphics/the-10-hottest-globalyears-on-record [Accessed: 8 May 2019].

Cook, J. et al. (2016). Consensus on consensus: a synthesis of consensus estimates on human-caused global warming. Environmental Research Letters, vol. 11(4), p. 048002. https://doi.org/10.1088/1748-9326/11/4/048002

Danielsen, O. (2015). Klimaet på dagsordenen. Dansk klimadebat 1988-2012. Copenhagen: Multivers.

Dearing, J. W. and Rogers, E. M. (1996). Agenda-Setting. Thousand Oaks: Sage.

EC (2018) Standard Eurobarometer 90 - Autumn 2018 "Public opinion in the European Union, First results". Brussels: European Commision, Directorate-General for Communication.

Eskjær, M. (2011). Klimaproblematikken som global fortælling. Medialisering af en senmoderne risiko. Akademisk kvarter, vol. 2, pp. 50-62.

Eskjær, M. (2014). Den danske presses klimadækning før og efter COP15. In: Sørensen, M. and Eskjær, M., eds, Klima og mennesker. Humanistiske perspektiver på klimaforandringer. København: Museum Tusculanum, pp. 145-173.

Eskjær, M. (2017). Climate Change Communication in Denmark. In: Oxford Research Encyclopedia on Climate Change. Oxford: Oxford UP. https://doi.org/10.1093/acrefore/9780190228620.013.452

Eskjær, M. and Helles, R. (2015) Kvantitativ Indholdsanalyse. Frederiksberg: Samfundslitteratur (Kort og præcist om medier og kommunikation).

Hall, S. et al. (1978). Policing the crisis: mugging, the state, and law and order. London: Macmillan (Critical social studies).

Hallin, D. C. (1986). The 'uncensored war': the media and Vietnam. New York: Oxford University Press.

Horsbøl, A. (2013). Energy Transition in and by the Local Media. Nordicom Review, vol. 34(2), pp. 19-34. https://doi.org/10.2478/nor-2013-0051

Horsbøl, A., Lassen, I. and Pedersen (2015). Klimaforandringer og hverdagsliv: en diskursanalytisk undersøgelse af lokale involveringsprocesser. University of Southern Denmark studies in history and social sciences, vol. 450. Odense: Syddansk Universitetsforlag.

Hulme, M. (2009). Why We Disagree About Climate Change. Understanding Controversy, Inaction and Opportunity. Cambridge: Cambridge UP.

Infomedia (2014). Mediernes doekning af energi og klima. En undersøgelse af de mest synlige aktører $i$ de danske mediers doekning af Energi og Klima i 2014. Copenhagen: Infomedia.

IPCC (2007). Climate Change 2007: Synthesis Report. Contribution of Working Groups I, II and III to the Fourth Assessment Report of the Intergovernmental Panel on 
Climate Change [Core Writing Team, Pachauri, R.K and Reisinger, A. (eds.)]. Geneva: IPCC, p. 104. Available at: http://www.ipcc.ch/ipccreports/ar4-syr.htm.

IPCC (2014) Summary for policymakers. In: Climate Change 2014: Impacts, Adaptation, and Vulnerability. Part A: Global and Sectoral Aspects. Contribution of Working Group II to the Fifth Assessment Report of the Intergovernmental Panel on Climate Change. Cambridge, United Kingdom and New York, USA: Cambridge University Press, pp. 1-32.

IPCC (2018). Global warming of $1.5^{\circ} \mathrm{C}$. IPCC. Available at: http://www.ipcc.ch/report/sr15/ [Accessed: 4 January 2019].

Jensen, C. (2018). Ikke mere snak. Lad os handle. Politiken (23 November), p. 1.

Jørgensen, A. S., Johansen, K. and Kabel, L. (2010a). Denmark: Failed Ambitions, People's Voices. In: Eide, E., Kunelius, R., and Kumpu, V., eds, Global climate, local journalisms: a transnational study of how media make sense of climate summits. Bochum: Projectverlag, pp. 147-164.

Jørgensen, A. S., Johansen, K. and Kabel, L. (2010b). Klimadoekning mellem drama og løsning, fiasko og folkelighed. Kvantitative analyser og journalistiske observationer af mediedcekning om og omkring COP 15-konferencen. Århus: Danmarks Medie og Journalisthøjskole. Available at: http://www.dmjx.dk/viden-og-innovation/artikler/klimadaekning-mellem-drama-og-konflikt-fiasko-og-folkelighed.

Lee, C.-C. et al. (2005). National Prisms of a Global "Media Event"". In: Curran, J. and Gurevitch, M., eds, Mass Media and Society. London: Arnold, pp. 320-335.

Lester, L. (2010). Media and Environment. Cambridge: Polity.

Levin, K. et al. (2012).Overcoming the tragedy of super wicked problems: constraining our future selves to ameliorate global climate change. Policy Sciences, vol. 45(2), pp. 123-152. https://doi.org/10.1007/s11077-012-9151-0.

Lidberg, J. (2018). Australian media coverage of two pivotal climate change summits. Pacific Journalism Review: Te Koakoa, vol. 24(1), pp. 70-86. https://doi.org/10.24135/pjr.v24i1.405

Lomborg, B. (1998), Verdens sande tilstand. 1. udg. Viby: Centrum.

Lomborg, B. (2001). The skeptical environmentalist: measuring the real state of the world. Cambridge, New York: Cambridge University Press.

Lomborg, B. (2007). Cool it: the skeptical environmentalist's guide to global warming. New York: Alfred A. Knopf.

Lomborg, B. (2009a). Global opvarmning kan standses. Jyllands-Posten (8 July).

Lomborg, B. (2009b). Lomborg: Opvarmning en fordel for rige lande. Jyllands-Posten (21 August).

Lomborg, B. (2015). Paven har forkert løsning på det rette problem. Berlingske (27 June).

McCombs, M. E. (2004). Setting the Agenda. The Mass Media and Public Opinion. Cambridge: Polity.

McCombs, M. E. and Shaw, D. L. (1972). The Agenda-setting Function of Mass Media. Public Opinion Quarterly, vol. 36(2), pp. 176-87.

McQuail, D. (2010). McQuail's Mass Communication Theory. 6th ed. London: Sage. 
Meilstrup, P. (2010). Kampen om klimaet: historien om et topmøde, der løb løbsk. Kbh.: People's Press.

Mollerup, J. (2018). Nyt koks i klimadækning. Politiken (18 October), p. 2.

Morton, T. (2013). Hyperobjects: philosophy and ecology after the end of the world. Minneapolis: University of Minnesota Press (Posthumanities, vol. 27).

Morton, T. (2016). Dark ecology: for a logic of future coexistence. New York: Columbia University Press (Wellek Library lectures in critical theory).

Oreskes, N. and Conway, E. M. (2010). Merchants of doubt: how a handful of scientists obscured the truth on issues from tobacco smoke to global warming. 1st U.S. ed. New York: Bloomsbury Press.

Painter, J. and Schäfer, M. S. (2018). Global Similarities and Persistent Differences: A Survey of Comparative Studies on Climate Change Communication. In: Brevini, B. and Lewis, J., eds, Climate Change and the media. N.Y.: Peter Lang.

Rittel, H. W. J. and Webber, M. M. (1973). Dilemmas in a general theory of planning. Policy Sciences, vol. 4(2), pp. 155-169. https://doi.org/10.1007/BF01405730

Rusbridger, A. (2015). Climate change: why the Guardian is putting threat to Earth front and centre. The Guardian (6 March).

Schäfer, M. S., Ivanova, A. and Schmidt, A. (2011). Globaler Klimawandel, globale Öffentlichkeit? Medienaufmerksamkeit für den Klimawandel in 23 Ländern. Studies in Communcation and Media, vol. 1, pp. 131-148.

Schäfer, M. S. and Schlichting, I. (2014). Media Representations of Climate Change: A Meta-Analysis of the Research Field. Environmental Communication, vol. 8(2), pp. 142-160. https://doi.org/10.1080/17524032.2014.914050

Skovgaard, J. and Blaxekjær, L. (2013). Global klimapolitik: Fra Bali til Paris. Tidsskriftet Politik, vol. 16(3), pp. 7-16.

The Guardian (2015). The biggest story in the world. Available at: https://www.theguardian.com/environment/series/the-biggest-story-in-the-world [Accessed: 5 August 2019].

UNFCCC (2015). Adoption of the Paris Agreement. Paris: United Nations Convention on Climate Change.

Urry, J. (2011). Climate Change \& Society. Cambridge: Polity.

WMO (2019). WMO confirms past 4 years were warmest on record. World Meterological Organization. Available at: https://public.wmo.int/en/media/press-release/wmoconfirms-past-4-years-were-warmest-record [Accessed: 10 May 2019].

Wold, M. (2015). Vatikanet har store klimaambitioner. Børsen (22 December). 